\title{
JAN PAWEE II A 1600. ROCZNICA SOBORU KONSTANTYNOPOLITAŃSKIEGO I
}

Sobór Konstantynopolitański I był ,po Soborze w Nicei - drugim Soborem powszechnym, któremu zawdzięczamy Credo, odmawiane stale w liturgii. Szczególnym dziedzictwem tego soboru jest nauka o Duchu Świętym"1. Tymi słowami Jan Paweł II rozpoczął zapowiedź jubileuszu 1600. rocznicy Soboru Konstantynopolitańskiego. W niniejszym przedłożeniu postaramy się zrelacjonować inicjatywy obchodów jubileuszu soborowego i zaangażowania weń papieża Jana Pawła II. Na pierwsze miejsce wysuwa się w tym kontekście List Apostolski A Concilio Constantinopolitano, z 25 marca 1981 r., który został napisany przez papieża z okazji wspomnianej rocznicy II Soboru Ekumenicznego oraz 1550. rocznicy Soboru Efeskiego ${ }^{2}$.

1 Jan Paweł II, Braterstwo - Wolność synów Bożych - Pokój. Przemówienie w czasie Mszy Świętej w Bazylice św. Piotra (1 I 1981), w: Nauczanie Papieskie, red. E. Weron - A. Jaroch (= NP), IV/1, Poznań 1989, Pallottinum, s. 2.

2 Jego tekst zob. AAS 73 (1981) 513-527; przekład polski: OsRomPol 2 (1981) nr 3, s. 12-13, przedruk VoxP 1 (1981) z. 1, 5-20. Do celów tego artykułu posługiwałem się jednak edycją pisma zamieszczoną w 1. części IV tomu Nauczania Papieskiego (NP IV/1, 393-400). Zamieszczony bowiem w „L'Osservatore Romano” tekst zawiera fatalną pomyłkę, którą potem prostowano w numerze 18(6) „L'Osservatore Romano” z czerwca 1981 r. na stronie 7. Błąd polegał na wpisaniu do cytowanego fragmentu oryginalnego wyznania wiary Soboru Konstantynopolitańskiego słynnego Filioque. Niestety kilka innych edycji Listu papieskiego poszło za błędną wersją, nie uwzględniając sprostowania, tak np. Wybór listów Ojca Świętego Jana Pawta II, II, Kraków 1997, 415, czy też VoxP 1 (1981) z. 1, 7-8. W edycji Pallottinum zaś błąd ten sprostowano. Na marginesie warto dodać, że poza Soborem Konstantynopolitańskim I i Efeskim jeszcze tylko jeden sobór starożytny doczekał się podobnego uczczenia. Był to Sobór Nicejski II, na którego 1200. rocznicę Jan Paweł II również napisał list apostolski, zob. Duodecimum saeculum, VoxP 10 (1990) z. 19, 559 569. Jeśli trzymać się logiki okrągłych rocznic, to pontyfikat Jana Pawła II dawał okazję do uczczenia jeszcze jednego z dwóch Soborów uznawanych za ekumeniczne - Konstantynopolitańskiego III (680-681) i Chalcedońskiego (451). Brak wspomnienia o III Soborze Konstantynopolitańskim nie dziwi, gdy spojrzymy nań w perspektywie braku jednomyślności między Wschodem i Zachodem, co do ekumenicznego charakteru tego zgromadzenia. To pominięcie w specyficzny sposób ujawnia jedną z dominant interesujących nas inicjatyw papieskich - ekumenizm. Obchody rocznicy Soborów w Konstantynopolu i Efezie, ale także II Soboru Nicejskiego były w jasno wyrażanej koncepcji Jana Pawła II elementami dialogu ekumenicznego z braćmi odłączonymi, 
List Apostolski nie był jednak jedyną inicjatywą, jaką Jan Paweł II podjął w związku z rocznicą II Soboru Ekumenicznego. Początek przygotowań do jubileuszu znaleźć można już we wspomnianym noworocznym orędziu wygłoszonym w czasie Mszy Świętej w Bazylice św. Piotra. Papież wskazując na główne akcenty rozpoczynającego się roku, poświęcił dwa akapity swojego przemówienia rocznicy I Soboru Konstantynopolitańskiego ${ }^{3}$.

Papież przygotował obchód jubileuszu, jako szereg wydarzeń o różnorodnym charakterze. Szczegółowy plan obchodów samego jubileuszu przedstawił we wspomnianym Liście A Concilio Constantinopolitano. Jan Paweł II zaprosił na wspólne świętowanie w Rzymie przedstawicieli wszystkich lokalnych episkopatów Kościoła łacińskiego oraz metropolii i patriarchatów wschodnich Kościołów katolickich. Centralne obchody zostały zaplanowane przez papieża na dzień Uroczystości Zesłania Ducha Świętego - 7 czerwca 1981. Przybyli goście mieli zgromadzić się rano pod przewodnictwem biskupa Rzymu w Bazylice św. Piotra na uroczystą liturgię Eucharystyczną ze śpiewem Credo Soboru Konstantynopolitańskiego. Druga część uroczystości jubileuszowych została zaplanowana na godziny popołudniowe jako pamiątka Soboru Efeskiego i z tej racji umiejscowiona w Bazylice Matki Bożej ${ }^{4}$. Faktycznie plan uroczystości został nieco poszerzony. Dodano jeszcze celebrację uroczystych nieszporów w Wigilię Uroczystości Zesłania Ducha Świętego ${ }^{5}$. Medytację w czasie tego nabożeństwa wygłosił prawosławny metropolita Damaskios z Tranaupolis ${ }^{6}$.

Udział Jana Pawła II w zapowiedzianej celebracji jubileuszu został bardzo skomplikowany przez tragiczne wydarzenia 13 maja 1981 roku. Zielone Święta, które były terminem uroczystości rocznicowych, wypadły w 1981 r., jak już wspomniano, 7 czerwca - w niecały miesiąc po zamachu na placu św. Piotra. Wprawdzie Jan Paweł II był po pierwszym etapie kuracji i 3 czerwca wrócił ze szpitala do pałacu apostolskiego, jednakże rozpoczął się już wówczas proces rozwoju infekcji, która zmusiła go do ponownej hospitalizacji, a nawet stanowiła w pewnym momencie poważne zagrożenie dla jego życia ${ }^{7}$. Wszystkie te okoliczności sprawiły, że Jan Paweł II nie mógł osobiście przewodniczyć uroczystościom jubileuszowym. Zdołał jedynie na moment pojawić się w we-

a nade wszystko z prawosławiem. Dziwi natomiast pominięcie tak dobrej ekumenicznej „okazji”, jaką była 1550. rocznica IV Soboru Ekumenicznego, która przypadała w 2001 roku.

3 Por. Braterstwo - Wolność synów Bożych - Pokój 2, NP IV/1, 2.

${ }^{4}$ Por. A Concilio Constantinopolitano 10-11, NP IV/1, 399-400.

5 Por. Kronika, OsRomPol 2 (1981) nr 6, s. 2.

${ }^{6}$ Por. Umiłujmy się wzajemnie. Medytacja w wigilię Zestania Ducha Świętego (6 VI 1981), OsRomPol 2 (1981) nr 6, s. 3-4.

7 Por. A. Frossard, ,Nie lękajcie się”. Rozmowy z Janem Pawłem II, tłum. A. Turowiczowa, Kraków 1983, 259-260; G. Weigel, Swiadek nadziei, tłum. M. Tarnowska i inni, Kraków 2000, 526527. 
wnętrznej loży Bazyliki Watykańskiej pod koniec celebracji eucharystycznej, stanowiącej kulminację obchodów i wygłosić krótkie przesłanie ${ }^{8}$. Ze swoich prywatnych apartamentów wygłosił również homilię do uczestników tejże Mszy Świętej, którą przekazano do wnętrza bazyliki na falach Radia Watykańskiego9 . Celebracji eucharystycznej w imieniu papieża przewodniczył ówczesny dziekan kolegium kardynałów Carlo Confalonieri. Warto dodać, że obecnych było na Mszy Świętej ponad 50 kardynałów i 250 biskupów reprezentujących episkopat całego świata oraz przedstawiciele innych Kościołów chrześcijańskich.

Równolegle z papieskimi obchodami w Rzymie odbywało się świętowanie jubileuszu II Soboru Ekumenicznego w Konstantynopolu. Na uroczystości te została wysłana delegacja pod przewodnictwem kardynała Maksymiliana de Fürstenberga. Papież zaopatrzył ją w osobisty list do patriarchy Dimitriosa $\mathrm{I}^{10}$.

Do rzymskich obchodów rocznicy Soboru Konstantynopolitańskiego I zaliczyć należy jeszcze międzynarodowy kongres teologiczny, zorganizowany w dniach 22-26 marca 1982 r. w auli synodu biskupów. Materiały z niego zostały wydane w dwóch opasłych (w sumie liczących ponad 1500 stron) tomach zatytułowanych: Credo in Spiritum Sanctum ${ }^{11}$. Jan Paweł II wziął udział w zakończeniu obrad Kongresu i wygłosił do zgromadzonych przemówienie ${ }^{12}$.

Tak przedstawiają się inicjatywy Jana Pawła II podjęte dla uczczenia 1600. rocznicy II Soboru Ekumenicznego. W drugiej części niniejszego przedłożenia chciałbym przedstawić najważniejsze wątki papieskich wystąpień i pism związanych z interesującą nas rocznicą. Pozwolę sobie zaniechać kursorycznej analizy każdego z dokumentów, a jedynie zaprezentuję powtarzające się w nich tematy.

Jako pierwszy temat przewijający się przez wszystkie dokumenty związane jubileuszem soboru w Konstantynopolu wymienić należy papieską wizję do-

${ }^{8}$ Por. Congregavit nos in unum Christi Amor. Przesłanie do uczestników liturgii eucharystycznej w Uroczystość Zesłania Ducha Świętego (7 VI 1981), OsRomPol 2 (1981) nr 6, s. 3.

9 Por. Wierzę w Ducha Świętego Pana i Ożywiciela. Homilia w Uroczystość Zestania Ducha Świętego (7 VI 1981), OsRomPol 2 (1981) nr 6, s. 4-5.

${ }^{10}$ Por. List do Jego Świątobliwości Dimitriosa I, OsRomPol 2 (1981) nr 6, s. 1 i 3.

11 Por. Credo in Spiritum Sanctum. Atti del Congresso Internazionale di Pneumatologia in occasione del $1600^{\circ}$ anniversario del I Concilio di Costantinopoli e del $1550^{\circ}$ anniversario del Concilio di Efeso, I-II, Roma 1983. Pisząc o rzymskim kongresie teologicznym trzeba przynajmniej jednym zdaniem wspomnieć, że wcześniej - wiosną 1981 r., odbył się inny kongres teologów upamiętniający rocznicę I Soboru Konstantynopolitańskiego, zorganizowany przez patriarchat ekumeniczny w jego europejskim ośrodku badań teologicznych w Chambésy koło Genewy. Materiały z tego zgromadzenia również zostały wydane i stanowią znakomitą syntezę stanu badań nad wydarzeniem II Soboru Ekumenicznego - La signification et l'actualité du II Conciles Oecuménique pour le monde chrétien d'aujourd'hui, Chambésy - Genève 1982.

12 Por. Wierność Duchowi Świętemu. Przemówienie do uczestników kongresu pneumatologicznego (26 III 1982), NP V/1, 449-454. 
konań tego zgromadzenia. W pismach i wypowiedziach Jana Pawła II nie pojawia się aspekt historyczny II Soboru Ekumenicznego. Papież nie podejmuje także dokonań tego zgromadzenia na płaszczyźnie eklezjologii. Widzi w nim jedynie kolegium, które dokonało ustalenia formuły wiary ${ }^{13}$.

Credo więc Soboru Konstantynopolitańskiego I jest centralnym tematem papieskich wypowiedzi i pism. Jan Paweł II przyjmuje bez żadnych zastrzeżeń tradycyjną tezę, iż formuła, o której mówimy, pochodzi od soboru z 381 roku ${ }^{14}$.

13 Najwyraźniej widać to w programowym, pierwszym punkcie papieskiego listu, por. A Concilio Constantinopolitano 1, NP IV/1,393-394. Podobnie jest w dalszych partiach listu i pozostałych pismach oraz wypowiedziach papieskich.

14 Por. Braterstwo - Wolność synów Bożych - Pokój 2, NP IV/1, 2; A Concilio Constantinopolitano 1, NP IV/1, 393-394; Wierzę w Ducha Świętego Pana i Ożywiciela 1, OsRomPol 2 (1981) nr 6, s. 4. Dyskusja o pochodzeniu i charakterze formuły nazwanej przez Sobór Chalcedoński Wiara 150-ciu Ojców z Konstantynopola ma długą historię i obfitą bibliografię. Żeby wymienić tylko najważniejsze pozycje w kolejności historycznej należy wspomnieć: F.J.A. Hort, Two Dissertations, Cambridge 1876; G. Rauschen, Jahrbücher der christlichen Kirche unter dem Kaiser Theodosius dem Grossen, Fribourg 1897; A. von Harnack, Konstantinopolitanisches Symbol, w: Realencyklopädie für protestantische Theologie und Kirche, XI, Leipzig 1902, 12-28; L. Duchesne, Autonimies ecclésiastiques. Églises separées, Paris 1905; C.J. Hefele - H. Leclercq, Histoire des conciles, II, Paris 1908; P. Batiffol, Le catholicisme des origines à saint Léon, t. 4: Le Siège apostolique (359-451), Paris 1924; Ch. Papadopoulos, Le Symbole du II Concile oecuménique, „Annuaire de la faculté de théologie de l'Université d'Athènes" 1 (1924) 1-73; E. Schwartz, Das Nicaenum und das Constantinopolitanum auf der Synode von Chalcedon, ZNW 25 (1926) 38-88; F.J. Badcock, The History of the Creeds, London 1930; J. Lebon, Nicée - Constantinople. Les premiers symboles de foi, RHE 32 (1936) 507-567; G. Bardy - J.R. Palanque, La victoire de l'orthodoxie, w: Histoire de l'Église, red. A. Fliche - V. Martin, III, Paris 1950, 277-296; A.M. Ritter, Das Konzil von Konstantinopel und sein Symbol. Studien zur Geschichte und Theologie des II. Ökumenischen Konzils, Göttingen 1965; D.L. Holland, The Creeds of Nicea and Constantinople reexamined, ChH 38 (1969) 1-14; E. Molland, „Des Reich kein Ende haben wird”. Hintergrund und Bedeutung einer dogmatischen Aussage im nicäno-constantinopolitanischen Glaubensbekenntnis, w: tegoż, Opuscula patristica, Oslo 1971, 235-253; J.N.D. Kelly, Altchristliche Glaubensbekenntnisse. Geschichte und Theologie, thum. K. Dockhorn, Berlin 1972; A. Grillmeier, Bekenntnisse der Alten Kirche, II: Das Nizäno-Constantinopolitanum, w: Studien zur Bekenntnisbildung, Wiesbaden 1980, 30-47; W.D. Hauschild, Die Trinitätslehre des Konzils von Konstantinopel und die Situation der Kirche im 4. Jahrhudert, w: La signification et l'actualité du II Conciles Oecuménique pour le monde chrétien d'aujourd'hui, Chambésy - Genève 1982, 213-234; A.M. Ritter, Das II. ökumenische Konzil und seine Rezeption. Stand der Forschung, w: La signification et l'actualité, s. 43-62; W. Schneemelcher, Die Entstehung des Glaubensbekenntnisses von Konstantinopel (381), w: La signification et l'actualité, s. 175-191; A. Grillmeier, Das nizaeno-konstantinopolitanische Glaubensbekenntnis, w: Das gemeinsame Credo: 1600. Jahre seit dem Konzil von Konstantinopel, red. Th. Piffl-Percević - A. Stirnemann, Innsbruck - Wien 1983, 48-52; A. de Halleux, La profession du l'Esprit Saint dans le Symbole de Constantinople, w tegoż: Patrologie et oecuménism. Recueil d'études, Leuven 1990, 303-337; R. Staats, Die römische Tradition im Symbol von 381 (NC) und seine Entstehung auf der Synode von Antiochien 379, VigCh 44 (1990) 209-221; L. Abramowski, Was hat das Nicaeno-Constantionopolitanum (C) mit dem Konzil von Konstantinopel zu tun?, ThPh 67 (1992) 481-513; A.M. Ritter, Noch einmal: „Was hat das Nicaeno-Constantionopolitanum (C) mit dem Konzil von Konstantinopel zu tun?", ThPh 68 (1993) 
Posługuje się też określeniem Credo Nicejsko-Konstantynopolitańskie ${ }^{15}$, która to nazwa, choć tradycyjna, nie jest najszczęśliwsza ${ }^{16}$. Z całego zaś wyznania Soboru Konstantynopolitańskiego podejmuje jedynie wątek pneumatologiczny w perspektywie ekonomii zbawienia ${ }^{17}$.

Problem, który stanąć musiał przed papieżem podejmującym temat formuły wiary II Soboru Ekumenicznego w perspektywie pneumatologii, była kwestia Filioque. W swoich pismach i wypowiedziach związanych z jubileuszem soborowym w 1981 r. Jan Paweł II nie zajął się wprost tą kwestią. Nadmienił o problemie w Liście do patriarchy Dimitriosa, ale zastrzegł od razu, że powinien on stać się przedmiotem dialogu między Kościołami ${ }^{18}$. Bardzo charakterystyczne jest jednak cytowanie przez Jana Pawła II wyznania wiary Soboru Konstantynopolitańskiego. Dwukrotnie posługując się słowami artykułu o Duchu Świętym Jan Paweł II podał jego oryginalne brzmienie - bez Filioque ${ }^{19}$.

Warto dodać w tym miejscu, że temat pochodzenia Ducha Świętego stał się przedmiotem specjalnego dokumentu, wydanego w 1996 r. przez Papieską Radę do spraw Popierania Jedności Chrześcijan ${ }^{20}$. Wprawdzie dokument ten nie wiąże się bezpośrednio z jubileuszem II Soboru Ekumenicznego, ale jest świadectwem intencji dialogu, jaką przy okazji jubileuszu wyraził Jan Paweł II.

Wyraźnie widać, że całe dzieło jubileuszu Soboru Konstantynopolitańskiego miało dla Jana Pawła II wymiar ekumeniczny. Do tematu jedności papież nawiązywał we wszystkich pismach i wypowiedziach związanych z jubileuszem. Podkreślał nade wszystko, że symbol pochodzący od Soboru Konstantynopolitańskiego jest wymownym znakiem jedności wszystkich chrześcijan ponad historycznymi podziałami ${ }^{21}$. Podziały te, pisał Jan Paweł

553-560; R. Staats, Das Glaubensbekenntnis von Nizäa-Konstantinopel. Historische und theologische Grundlagen, Darmstadt 1996.

15 Por. A Concilio Constantinopolitano 8, NP IV/1, 398; List do Jego Świątobliwości Dimitriosa I, OsRomPol 2 (1981) nr 6, s. 1; Wierzęw Ducha Świętego Pana i Ożywiciela 1, OsRomPol 2 (1981) nr 6, s. 4.

16 Por. M. Starowieyski, Sobory Kościoła niepodzielonego, Tarnów 1994, 44.

17 Por. A Concilio Constantinopolitano 1, 3 i 7, NP IV/1, 394-397; Wierzę w Ducha Świętego Pana i Ożywiciela 2, OsRomPol 2 (1981) nr 6, s. 5; Wierność Duchowi Świętemu 4, NP V/1, 452.

18 Por. List do Jego Świątobliwości Dimitriosa I, OsRomPol 2 (1981) nr 6, s. 3.

19 Por. A Concilio Constantinopolitano 2, NP IV/1, 394-395; Wierzę w Ducha Świętego Pana i Ożywiciela 1, OsRomPol 2 (1981) nr 6, s. 4; zob. też na ten temat: J.M. Garrigues, Le Filioque hier et aujourd'hui, w: Credo in Spiritum Sanctum. Atti del Congresso Internazionale di Pneumatologia in occasione del $1600^{\circ}$ anniversario del I Concilio di Costantinopoli e del $1550^{\circ}$ anniversario del Concilio di Efeso, I, Roma 1983, 345-348.

${ }^{20}$ Por. Pontificium Consilium ad Christianorum Unitatem Fovendam, Les traditions grecque et latine concernant la procession du Saint - Esprit, Roma 1996. Tekst dokumentu ukazał się równolegle w języku francuskim, greckim, angielskim i rosyjskim.

${ }^{21}$ Por. A Concilio Constantinopolitano 1, NP IV/1, 394; Wierzę w Ducha Świętego Pana i Ożywiciela, OsRomPol 2 (1981) nr 6, s. 4; Wierność Duchowi Świętemu 2, NP V/1, 450. 
II, mogą być pokonane przez dialog prowadzony pod natchnieniem Ducha Świętego, w którego wiarę sobór wyznał i utwierdził ${ }^{22}$. Papież wyrażał szczerą nadzieję, iż świętowanie jubileuszu soborowego ożywi dialog i przybliży perspektywę jedności ${ }^{23}$.

Pośród wszystkich wątków pojawiających się w pismach i wypowiedziach papieskich związanych z jubileuszem, najczęstszym i najbardziej wyrazistym było wskazywanie analogii pomiędzy I Soborem Konstantynopolitańskim i II Watykańskim. Papież podkreślał, iż dzieło obydwu soborów dokonało się pod natchnieniem tego samego Ducha ${ }^{24}$. Dlatego też doktryna wyznana w Konstantynopolu została uroczyście potwierdzona na Soborze Watykańskim II $^{25}$. Jan Paweł II przypominał, że Duch Święty, którego boskości i czci bronili Ojcowie w Konstantynopolu, ożywia Kościół i prowadzi do realizacji tego, co pod Jego natchnieniem zostało podjęte na Soborze Watykańskim II ${ }^{26}$. Warto zauważyć, że dokumenty Vaticanum II są najliczniej cytowanymi, poza Credo Soboru Konstantynopolitańskiego, tekstami. W tym kontekście zastanawia nawet prawie zupełny brak odniesień patrystycznych w listach i przemówieniach Jana Pawła II, związanych z omawianym jubileuszem ${ }^{27}$.

Podsumowując można powiedzieć, że dla Jana Pawła II Sobór Konstantynopolitański I to nade wszystko Credo, które stanowi wspólne dziedzictwo wszystkich wyznań chrześcijańskich. Soborowy symbol stanowi zwornik nie tylko między poszczególnymi denominacjami chrześcijańskimi, ale także oś jedności w czasie. Kościół (Kościoły) przyjmując Wiarę 150 Ojców z Konstantynopola przez wieki świadczył o swojej tożsamości w czasie i łączności z poprzednimi pokoleniami wierzących. Szczególnym wyrazem tej jedności w czasie jest przyjęcie symbolu z Konstantynopola przez Sobór Watykański II. Cały zaś uroczysty obchód jubileuszu soborowego miał dla Jana Pawła II podwójny charakter - refleksji teologicznej i wezwania pasterskiego ${ }^{28}$.

22 Por. List do Jego Świątobliwości Dimitriosa I, OsRomPol 2 (1981) nr 6, s. 3; Wierzę w Ducha Świętego Pana i Ożywiciela 2, OsRomPol 2 (1981) nr 6, s. 4-5; Wierność Duchowi Świętemu 5, NP $\mathrm{V} / 1,453$.

23 Por. A Concilio Constantinopolitano 5, NP IV/1, 396.

${ }^{24}$ Por. Wierność Duchowi Świętemu 2-3, NP V/1, 450-451.

25 Por. A Concilio Constantinopolitano 6, NP IV/1, 397.

26 Por. Wierze w Ducha Świętego Pana i Ożywiciela 2, OsRomPol 2 (1981) nr 6, s. 4-5.

27 Wprost zacytowany został tylko traktat $O$ Duchu Świętym św. Ambrożego, por. A Concilio Constantinopolitano 1, NP IV/1, 394. W kontekście jubileuszu Soboru Efeskiego wspomniane, ale bez cytatu, są jeszcze Listy do Nestoriusza św. Cyryla Aleksandryjskiego oraz Formula unionis z 433 r., zob. A Concilio Constantinopolitano 3, NP IV/1, 395.

28 Por. A Concilio Constantinopolitano 1, NP IV/1, 393-394. 


\section{JOHANNES PAUL II UND 1600. JAHRESTAG DES ERSTE KONZILS VON KONSTANTINOPEL}

\section{(Zusammenfassung)}

Für Johannes Paul II. war das erste Konzil von Konstantinopel primär mit dem Credo verbunden, das zum gemeinsamen Nachlass aller christlichen Denominationen wurde. Das Symbol von Konstantinopel ist nicht nur ein Bindeglied zwischen einzelnen christlichen Konfessionen, sondern fokussiert diese auch zeitlich. Indem die Kirche(n) den Glauben von 150. Vätern von Konstantinopel annahm, zeugte sie durch Jahrhunderte lang von ihrer zeitlichen Identität und Verbindung mit früheren Generationen der Gläubigen. Zum signifikanten Ausdruck dieser zeitlichen Einheit wurde die Annahme des Glaubensbekenntnisses von Konstantinopel durch das zweite Vatikanische Konzil. Die von Johannes Paul II. veranstalteten Feierlichkeiten zum 1600. Jahrestag des Konzils hatten den doppelten Charakter - der theologischen Reflexion und pastoralen Aufforderung. 